\title{
Bioassay-Guided Isolation, Purification and Charaterization of Antimicrobial Compound From Acidic Metabolite of Piper umbellatum Seed Extract
}

\author{
A. E. Ejele ${ }^{1}$, C. I. Akalezi ${ }^{1}$, I. C. Iwu ${ }^{1}$, L. N. Ukiwe ${ }^{1}$, C. K. Enenebaku ${ }^{1} \&$ S. U. Ngwu ${ }^{2}$ \\ ${ }^{1}$ Department of Chemistry, Federal University of Technology, Owerri, Owerri. Imo State, Nigeria \\ ${ }^{2}$ Department of Chemistry, Alvan Ikoku Federal College of Education, Owerri, Owerri. Imo State, Nigeria \\ Correspondence: A. E. Ejele, Department of Chemistry, Federal University of Technology, Owerri, PMB 1526, \\ Owerri. Imo State, Nigeria. Tel: 234-803-735-9251. E-mail: monyeejele@yahoo.com
}

\author{
Received: April 6, 2013 Accepted: May 15, 2013 Online Published: January 2, 2014 \\ doi:10.5539/ijc.v6n1p61 URL: http://dx.doi.org/10.5539/ijc.v6n1p61
}

\begin{abstract}
The antimicrobial potential of ethanol extract of Piper umbellatum seeds and its acidic, basic and neutral metabolites were evaluated using the disc diffusion method. The results showed that the acidic and neutral metabolites exhibited greater antibiotic activities against the tested microorganisms; Coliform bacilli, Salmonella typhi and Staphylococcus aureus and gave inhibition zone diameters greater than $28 \mathrm{~mm}$ against both C. bacilli and S. aureus. These results were interpreted in terms of differences in phytochemical composition of these metabolites and indicated that an effective anti-Staphylococcal drug could be developed from P. umbellatum extract for chemotherapy of diseases caused by $S$. aureus, which is known all over the world to develop resistance to most potent antibiotic drugs. Chromatographic purification of the acidic metabolite gave five fractions whose antimicrobial potential against some pathogens was evaluated and compared with Amoxil (a positive standard antimicrobial drug). The results showed that all the chromatographic fractions possessed inhibitory activities against the tested microbes. Spectroscopic analysis of IR, ${ }^{1} \mathrm{H}-$ and ${ }^{13} \mathrm{C}-\mathrm{NMR}$ data suggested that the active principle in acidic metabolite of $P$. umbellatum could be Naringin, a naturally occurring polyphenol and antibiotic drug.
\end{abstract}

Keywords: isolation, characterization, active principle, acidic metabolite, Piper umbellatum

\section{Introduction}

Medicinal plants often exhibit a wide range of biological and pharmacological activities, such as anti-inflammatory, antibacterial and antifungal properties (Ajayi et al., 2011). It is generally assumed that the active constituents contributing to these protective effects are phytochemicals, vitamins and minerals (Okwu, 2005). Phytochemicals are natural products derived from plant sources, whose isolation and modification have led to production of numerous useful drugs. Due to the need for development of new drugs with better pharmacological activities, the dependence on plants grew increasingly as scientists continually exploited them for isolation of bioactive compounds. Several plant extracts have been shown to possess remarkable potential in prevention of microbial spoilage of food products (Okwu, 2005; Jussi-Pekka et al., 2000; Smith-Palmer et al., 2001; Kotzekidou et al., 2008; Ejele, 2010; Ugbogu et al., 2010). The inhibition of growth and activity of microorganisms is one of the major uses of chemical preservatives in the food industry. Many antibiotics have also been used as preservatives for raw foods, especially protein foods like meat, fish, poultry, etc. but microorganisms often formed resistance against them and new strains of these organisms developed (WHO report, 1974; Levy, 1998) hence the use of medicinal plant extracts and metabolites have become necessary.

The phytochemistry and antimicrobial potentials of plant extracts and secondary metabolites have been investigated by several workers (Anesini \& Perez, 1993; Adesokan et al., 2007; Mahesh \& Satish, 2008; Alinnor \& Ejele, 2009; Ejele \& Alinnor, 2010; Ejele \& Akujobi, 2011). Anesini and Perez (1993) tested 122 plant species often used for local treatment of several diseases and found that twelve plant species inhibited growth of Staphylococcus aureus, ten were effective against Escherichia coli while four inhibited Aspergillus niger. Adesokan et al. (2007) studied the aqueous extract of the stem bark of Enantia chlorantha and found that it possessed broad-spectrum antibacterial activities with gram-positive bacteria showing more susceptibility to the 
extract at all concentrations. The authors concluded that the broad-spectrum antibacterial activity of the plant extract was possibly due to the presence of alkaloids.

Alinnor and Ejele (2009) studied the antimicrobial properties of crude extracts of Gongronema lafolium and found that ethanol extract inhibited growth of S. aureus, E. coli, P. aeruginosa, and P. vulgaria. Ejele and Akujobi (2011) studied the effects of acidic, basic and neutral metabolites of Garcinia kola on the microbial spoilage of Cajanus cajan extract and found that the acidic metabolite completely inhibited the microbial attack on C. cajan extract throughout the study period of one year, suggesting that the acidic metabolite of G. kola possesses antimicrobial and antifungal properties. Moreover the antimicrobial screening of the acidic metabolite on some human pathogens, such as E. coli, S. aureus, C. bacilli, and S. typhi and showed that the acidic metabolite was effective against all the human pathogens tested.

Black pepper (P. umbellatum) originates from tropical America and widely naturalized throughout the tropics. It is found in tropical Africa from Guinea and Cameroun to Ethiopia and Southern Africa. In traditional Africa medicine, a decoction of the leaves or roots of $P$. umbellatum is used for the relief of jaundice, malaria, urinary and kidney problems, syphilis and gonorrhea, leucorrhoea, menstrual problems, and stomach-ache, while the leaves are widely used as an emollient and antiseptic and applied on boils, burns and swellings. The antimicrobial potential of pepper extracts have been investigated (Pundir \& Jain, 2010; Ejele et al., 2012). Pundir and Jain (2010) carried out a comparative study of the antimicrobial activities of $P$. nigrum extract and found that both ethanol and methanol extracts of the plant were effective against food spoilage bacteria and fungi. The authors observed that aqueous extract of black pepper showed strong activity against $S$. auerus while the ethanol and methanol extracts were effective against all the tested food spoilage bacteria such as B.megaterium, $B$. sphaericus, B. polymyxa, S. auerus and E. coli suggesting that ethanolic and methanolic extracts of black pepper contained antimicrobial compounds which could be suitable alternatives to chemical preservative. Ejele et al. (2012) compared the antimicrobial potential of neutral metabolites and found that the metabolite of $P$. umbellatum seeds and $N$. laevis leaves extracts exhibited strong antimicrobial activities against the tested microorganisms, C. bacilli, S. typhi and S. aureus. The results showed that the greatest activity of the $P$. umbellatum neutral metabolite was against $S$. aureus with inhibition zone diameter of $29 \pm 4 \mathrm{~mm}$ at $100 \mathrm{mg} / \mathrm{ml}$ concentration while the least activity was against $S$. typhi with inhibition zone of $25 \pm 3 \mathrm{~mm}$, at the same concentration suggesting that the neutral metabolite of $P$. umbellatum could be an important source of useful antimicrobial compound that may be employed in the treatment of infections caused by several human pathogens which are microorganisms that cause various diseases (Pundir \& Jain, 2010; Ejele et al., 2012). In a recent study A. E. Ejele and N. U. Ejele (2012) evaluated the antimicrobial potential of crude extract, acidic, basic and neutral metabolites of $P$. umbellatum seeds extract against selected human pathogens and found that both crude extract and metabolites possessed antimicrobial activity against the tested microorganisms, C. bacilli, S. typhi and S. aureus although the acidic and neutral metabolites were more effective than the basic against $C$. bacilli and $S$. aureus with inhibition zone diameters greater than $28 \pm 4 \mathrm{~mm}$ at $100 \mathrm{mg} / \mathrm{ml}$ concentration.

However, the active principles responsible for the observed antimicrobial properties are not known with certainty hence concerted efforts should be made to isolate and characterize the active principle responsible for the observed antibiotic effects. In this regard, Tabopda et al. (2008) isolated and characterized four alkaloids from branches of $P$. umbellatum and showed they possessed $\alpha$-glycosidase inhibition, antioxidant and antifungal activities while Baldoqui et al. (2009) reported the isolation and characterization of nine compounds from leaves of P. umbellatum including one terpenoid, five flavones and two lignans. In this paper we report the isolation, purification and characterization of an antibiotic compound from the acidic metabolite of $P$. umbellatum seeds with a view to identify the phytochemical compound responsible for the observed antimicrobial and preservative properties of the plant.

\section{Method}

\subsection{Preparation of P. umbellatum Seed Extract}

Sixty five gram of sun dried seeds of $P$. umbellatum were ground and put in a soxhlet extractor fitted with a reflux condenser and extracted with $250 \mathrm{ml}$ of ethanol for $12 \mathrm{~h}$. The ethanol extract was allowed to evaporate completely at room temperature to give a gel, which was dissolved in ethanol/water mixture (4:1) and filtered. The filtrate was used without further purification for antimicrobial experiments and preparation of acidic, basic and neutral metabolites. Phytochemical screening of this filtrate showed presence of alkaloids, amino acids, flavonoids, carboxylic acids, glycosides, saponins and tannins. 


\subsection{Preparation of Metabolites}

\subsubsection{Preparation of Basic Metabolite}

This metabolite was prepared as earlier stated (Ejele \& Alinnor, 2010). The filtrate of $P$. umbellatum seed extract was treated with diluted $2 \mathrm{M} \mathrm{HCl}$ and extracted with chloroform in a separatory funnel. The lower chloroform layer was removed (and reserved for the preparation of other metabolites). The $\mathrm{HCl}$ layer was treated with diluted $2 \mathrm{M} \mathrm{NaOH}$ solution until the mixture became basic. Then the resultant solution (with or without precipitate) was allowed to evaporate completely at room temperature to form a gel, which was dissolved in $95 \%$ ethanol and filtered. The filtrate was used without further purification for antimicrobial and phytochemical experiments Preliminary phytochemical screening of this filtrate showed presence of alkaloids, amino acids, glycosides, saponins and tannins.

\subsubsection{Preparation of Neutral Metabolite}

The chloroform layer obtained above was placed in a separatory funnel and treated with diluted $2 \mathrm{M} \mathrm{NaOH}$ solution. After equilibrating, two layers were obtained. The chloroform layer was removed and allowed to evaporate completely at room temperature to produce a gel, which was dissolved in $95 \%$ ethanol and filtered. The filtrate was used without further purification for the antimicrobial and phytochemical experiments (Levy, 1998). Preliminary phytochemical screening of this filtrate showed the presence of amides, esters, steroids and terpenoids. The aqueous $2 \mathrm{M} \mathrm{NaOH}$ layer was removed and used for preparation of acidic metabolites.

\subsubsection{Preparation of Acidic Metabolite}

The aqueous alkaline layer obtained above was treated with diluted $2 \mathrm{M} \mathrm{HCl}$ until the solution became acidic. The mixture (with or without precipitate) was allowed to evaporate completely at room temperature to produce gel, which was dissolved in $95 \%$ ethanol and filtered. The filtrate was used without further purification for antimicrobial and phytochemical experiments (Ejele \& Alinnor, 2010). Preliminary phytochemical tests carried out on this filtrate showed contained amino acids, fatty acids, flavonoids and free phenols.

\subsection{Antimicrobial Analysis of Extract and Metabolites}

The experiments were carried out in the Microbiology Department, Federal Medical Centre, Owerri, Imo State of Nigeria. Tested microorganisms used were C. bacilli, S. typhi and S. aureus and the method used was agar disc diffusion method. An inoculating loop was touched to three isolated colonies of the pathogen on an agar plate and used to inoculate a tube of culture broth, which was incubated at $35-37^{\circ} \mathrm{C}$ until it became slightly turbid and was diluted to match the turbidity standard. Then a sterile cotton swab was dipped into the standardized bacterial test suspension and used to evenly inoculate the entire surface of the agar plate. After $5 \mathrm{~min}$, the appropriate antibiotic test disks which were prepared by dipping the test disks into appropriate antibiotic mixture (extract or metabolite) and placed with a multiple applicator device on the agar plate. The agar plate (loaded with the antibiotic test disks) was incubated at $35-37{ }^{\circ} \mathrm{C}$ for $16-18$ hours, after which the diameters of inhibition zones (areas showing little or no microbial growth) were measured to the nearest mm (Garred \& Graddy, 1983; Harbarth \& Samore, 2005; Juruya \& Lowry, 2006) The same solvent (95\% ethanol) was used to dissolve metabolites and extracts prior to antimicrobial analysis, hence control experiments were carried out to evaluate antimicrobial activity of the solvent, which showed the solvent possessed little or no antimicrobial activity against the tested microorganisms.

\subsection{Phytochemical Tests on Extract and Metabolites}

Phytochemical screening of extract and metabolites for the presence of amino acids, alkaloids, cardiac glycosides, flavonoids, saponins, steroids, tannins and triterpenes were carried using standard methods (Evans, 2002).

\subsection{Qualitative TLC Tests on Acidic Metabolite}

This test was conducted to determine the number of compounds present in the acidic metabolite. The metabolite was dissolved in ethanol and spotted several times onto the TLC plate (coated with silica gel) using a micro capillary tube until the quantity loaded was adjudged sufficient for the experiment. The plate was placed in a glass tank containing the mobile phase (chloroform/ethanol; ratio 1:1) and allowed to run until the moving phase reached the top of the plate, after which the plate was removed, dried in air and developed in iodine tank. The $\mathrm{R}_{\mathrm{f}}$ values of the various components were determined.

\subsection{Chromatographic Purification}

The qualitative TLC test performed above showed the presence of three compounds in the acidic metabolite hence column chromatographic purification was performed to separate the different components. 


\subsubsection{Procedure}

Slurry of silica gel (stationary phase) was prepared in chloroform and packed into a column of $2.5 \mathrm{~cm}$ diameter to a high of $12.5 \mathrm{~cm}$ Then $5 \mathrm{ml}$ of acidic metabolite, dissolved in ethanol was transferred gently onto the top of column and allowed to flow into the packed silica gel column while the tap was opened. The mixture was eluted by gradient elution with chloroform and ethanol during which it was separated into several fractions, which were collected in separate containers and numbered.

\subsection{Antimicrobial Analysis of Chromatographic Fractions}

The antimicrobial screening of various fractions obtained from the chromatographic purification of the acidic metabolite was carried out at the Department of Microbiology, Federal Medical Centre, Owerri, Imo State of Nigeria, using the disk diffusion method as earlier described (Garred \& Graddy, 1983; Harbarth \& Samore, 2005; Juruya \& Lowry, 2006). The inhibition zone diameters were measured and the fraction that showed the best antibiotic activity was chosen for IR and NMR spectroscopic analyses and structural elucidation.

\subsection{Spectroscopic Analysis}

Infra Red analysis of the selected chromatographic fraction was performed at Central Research Laboratory, University of Ibadan, Nigeria using FTIR Infra Red Spectrophotometer BX-model manufactured by Perkin Elmer while the ${ }^{1} \mathrm{H}-$ and ${ }^{13} \mathrm{C}-\mathrm{NMR}$ analyses were performed at Obafemi Awolowo University, Ile-Ife, Nigeria using the V-NMR1 Mercury-20088. Solvents used for the NMR analyses were $\mathrm{CH}_{3} \mathrm{OD}, \mathrm{CDCl}_{3}$ or DMSO.

\section{Results}

\subsection{Antimicrobial Screening of Various Metabolites}

The results of antimicrobial screening of the crude extract and various metabolites were shown in Table 1 while Tables 2-5 showed their respective MICs. It was observed from Table 1 that all the samples possessed antimicrobial activity to various extents. The table showed that the crude extract exhibited its greatest activity against $C$. bacilli with inhibition zone of $27 \pm 3 \mathrm{~mm}$ at $100 \mathrm{mg} / \mathrm{ml}$ and MIC of $6.25 \mathrm{mg} / \mathrm{ml}$ (Table 2) while the least activity was against $S$. aureus with inhibition zone of $15 \pm 4 \mathrm{~mm}$ and MIC of $25 \mathrm{mg} / \mathrm{ml}$ (Table 2). Positive control used was Amoxil at $200 \mathrm{mg} / \mathrm{ml}$ concentration (Table 1) while the negative control was diluted (2M) sodium chloride solution. The acidic metabolite exhibited its greatest activity against $S$. aureus with inhibition zone of $32 \pm 3 \mathrm{~mm}$ at $100 \mathrm{mg} / \mathrm{ml}$ concentration and MIC of $6.25 \mathrm{mg} / \mathrm{ml}$ (Table 3), closely followed by C. bacilli with inhibition zone of $30 \pm 2 \mathrm{~mm}$ and MIC of $6.25 \mathrm{mg} / \mathrm{ml}$ while $S$. typhi was the least susceptible to this metabolite with inhibition zone of $22 \pm 4 \mathrm{~mm}$ at $100 \mathrm{mg} / \mathrm{ml}$ and MIC of $25 \mathrm{mg} / \mathrm{ml}$ (Table 3).

When compared with the crude extract it was clearly seen that antimicrobial activity of the acidic metabolite against $S$. aureus was significantly enhanced and inhibition zone increased from $15 \pm 4 \mathrm{~mm}$ (for crude extract) to $32 \pm 3 \mathrm{~mm}$ (for metabolite) at $100 \mathrm{mg} / \mathrm{ml}$ concentration. However, the activity of acidic metabolite (or fraction) against $S$. typhi was not significantly different from that of the crude extract. Table 1 also gave antimicrobial activity of the basic metabolite from which it could be seen that $C$. bacilli was most susceptible to the basic metabolite with inhibition zone of $20 \pm 4 \mathrm{~mm}$ at $100 \mathrm{mg} / \mathrm{ml}$ concentration and MIC of $6.25 \mathrm{mg} / \mathrm{ml}$ (Table 4) while $S$. aureus with an inhibition zone diameter of $15 \pm 5 \mathrm{~mm}$ was the least susceptible at the same concentration and MIC of $50 \mathrm{mg} / \mathrm{ml}$ (Table 4).

In comparison with the crude extract, it was observed that antimicrobial activities of the basic metabolite against C. bacilli and S. typhi were significantly smaller and inhibition zone diameters decreased from $27 \pm 3$ and $21 \pm 3$ $\mathrm{mm}$ respectively (for crude extract) to $20 \pm 4$ and $18 \pm 3 \mathrm{~mm}$ (for metabolite) at the same concentration. The antimicrobial activity against $S$. aureus was unaffected. The activity of neutral metabolite was also presented in Table 1 while the MIC was shown in Table 5. Table 1 showed that the greatest antimicrobial activity of this metabolite was against $S$. aureus, with inhibition zone of $29 \pm 3 \mathrm{~mm}$ at $100 \mathrm{mg} / \mathrm{ml}$ concentration while Table 5 showed its MIC was $12.5 \mathrm{mgml}$. The metabolite inhibited the growth of C. bacilli with inhibition zone of $28 \pm 4$ $\mathrm{mm}$ and MIC of $6.25 \mathrm{mg} / \mathrm{ml}$. The least activity was against $S$. typhi with inhibition zone of $25 \pm 4 \mathrm{~mm} 25 \mathrm{mg} / \mathrm{ml}$. When compared with the crude extract, it was observed that the activities of neutral metabolite against $C$. bacilli and $S$. typhi were not significantly affected whereas the activity against $S$. aureus was enhanced and the inhibition zone diameter increased from $15 \pm 4 \mathrm{~mm}$ (for extract) to $29 \pm 3 \mathrm{~mm}$ (for metabolite) at $100 \mathrm{mg} / \mathrm{ml}$ concentration (Table 5). In Table 4 was presented the MIC of basic metabolite, from which it could be seen that C. bacilli was most susceptible with IZD of $20 \pm 4 \mathrm{~mm}$ and MIC of $6.25 \mathrm{mg} / \mathrm{ml}$ while $S$. aureus was the least susceptible with IZD of $15 \pm 5 \mathrm{~mm}$ at $100 \mathrm{mg} / \mathrm{ml}$ concentration and MIC of $50 \mathrm{mg} / \mathrm{ml}$. The MIC of neutral metabolite was presented in Table 5 and showed this metabolite had its greatest activity against $S$. aureus, with IZD of $29 \pm 3 \mathrm{~mm}$ at $100 \mathrm{mg} / \mathrm{ml}$ concentration and MIC of $12.5 \mathrm{mgml}$ while the least activity was against $S$. typhi 
with IZD of $25 \pm 4 \mathrm{~mm}$ and MIC of $25 \mathrm{mg} / \mathrm{ml}$.

Table 1. Comparison of antimicrobial activities of various metabolites (Metabolite Concentration $=100 \mathrm{mg} / \mathrm{ml}$; Amoxil concentration $=200 \mathrm{mg} / \mathrm{ml} ; \mathrm{IZD}=\mathrm{mm} \pm$ std dev.)

\begin{tabular}{llllll}
\hline $\begin{array}{l}\text { Test } \\
\text { microorganism }\end{array}$ & $\begin{array}{l}\text { Crude } \\
\text { extract }\end{array}$ & $\begin{array}{l}\text { Acidic } \\
\text { metabolite }\end{array}$ & $\begin{array}{l}\text { Basic } \\
\text { metabolite }\end{array}$ & $\begin{array}{l}\text { Neutral } \\
\text { metabolite }\end{array}$ & $\begin{array}{l}\text { Amoxil (positive } \\
\text { control) }\end{array}$ \\
\hline C. bacilli & $27 \pm 3 \mathrm{~mm}$ & $30 \pm 2 \mathrm{~mm}$ & $20 \pm 4 \mathrm{~mm}$ & $28 \pm 4 \mathrm{~mm}$ & $15 \pm 2 \mathrm{~mm}$ \\
S. typhi & $21 \pm 3 \mathrm{~mm}$ & $22 \pm 4 \mathrm{~mm}$ & $18 \pm 3 \mathrm{~mm}$ & $25 \pm 4 \mathrm{~mm}$ & $13 \pm 3 \mathrm{~mm}$ \\
S. aureus & $15 \pm 4 \mathrm{~mm}$ & $32 \pm 3 \mathrm{~mm}$ & $15 \pm 5 \mathrm{~mm}$ & $29 \pm 3 \mathrm{~mm}$ & $19 \pm 4 \mathrm{~mm}$ \\
\hline
\end{tabular}

Table 2. Determination of MIC of crude extract

\begin{tabular}{lccccc}
\hline Microorganism & $100 \mathrm{mg} / \mathrm{ml}$ & $50 \mathrm{mg} / \mathrm{ml}$ & $25 \mathrm{mg} / \mathrm{ml}$ & $12.5 \mathrm{mg} / \mathrm{ml}$ & $6.25 \mathrm{mg} / \mathrm{ml}$ \\
\hline C. bacilli & $27 \pm 3 \mathrm{~mm}$ & $24 \pm 3 \mathrm{~mm}$ & $20 \pm 4 \mathrm{~mm}$ & $10 \pm 2 \mathrm{~mm}$ & $8 \pm 2 \mathrm{~mm}$ \\
S. typhi & $21 \pm 3 \mathrm{~mm}$ & $15 \pm 4 \mathrm{~mm}$ & $8 \pm 3 \mathrm{~mm}$ & $2 \pm 1 \mathrm{~mm}$ & - \\
S. aureus & $15 \pm 3 \mathrm{~mm}$ & $10 \pm 4 \mathrm{~mm}$ & $5 \pm 2 \mathrm{~mm}$ & - & - \\
\hline
\end{tabular}

Table 3. Determination of MIC of acidic metabolite

\begin{tabular}{lccccc}
\hline Microorganism & $100 \mathrm{mg} / \mathrm{ml}$ & $50 \mathrm{mg} / \mathrm{ml}$ & $25 \mathrm{mg} / \mathrm{ml}$ & $12.5 \mathrm{mg} / \mathrm{ml}$ & $6.25 \mathrm{mg} / \mathrm{ml}$ \\
\hline C. bacilli & $30 \pm 2 \mathrm{~mm}$ & $26 \pm 3 \mathrm{~mm}$ & $21 \pm 2 \mathrm{~mm}$ & $18 \pm 4 \mathrm{~mm}$ & $10 \pm 3 \mathrm{~mm}$ \\
S. typhi & $22 \pm 4 \mathrm{~mm}$ & $15 \pm 3 \mathrm{~mm}$ & $10 \pm 3 \mathrm{~mm}$ & - & - \\
S. aureus & $32 \pm 3 \mathrm{~mm}$ & $26 \pm 4 \mathrm{~mm}$ & $20 \pm 3 \mathrm{~mm}$ & $15 \pm 4 \mathrm{~mm}$ & $9 \pm 3 \mathrm{~mm}$ \\
\hline
\end{tabular}

Table 4. Determination of MIC of basic metabolite

\begin{tabular}{lccccc}
\hline Microorganism & $100 \mathrm{mg} / \mathrm{ml}$ & $50 \mathrm{mg} / \mathrm{ml}$ & $25 \mathrm{mg} / \mathrm{ml}$ & $12.5 \mathrm{mg} / \mathrm{ml}$ & $6.25 \mathrm{mg} / \mathrm{ml}$ \\
\hline C. bacilli & $20 \pm 4 \mathrm{~mm}$ & $18 \pm 3 \mathrm{~mm}$ & $14 \pm 4 \mathrm{~mm}$ & $12 \pm 3 \mathrm{~mm}$ & $8 \pm 4 \mathrm{~mm}$ \\
S. typhi & $18 \pm 3 \mathrm{~mm}$ & $15 \pm 4 \mathrm{~mm}$ & $13 \pm 3 \mathrm{~mm}$ & $7 \pm 2 \mathrm{~mm}$ & - \\
S. aureus & $15 \pm 5 \mathrm{~mm}$ & $9 \pm 3 \mathrm{~mm}$ & - & - & - \\
\hline
\end{tabular}

Table 5. Determination of MIC of neutral metabolite

\begin{tabular}{lccccc}
\hline Microorganism & $100 \mathrm{mg} / \mathrm{ml}$ & $50 \mathrm{mg} / \mathrm{ml}$ & $25 \mathrm{mg} / \mathrm{ml}$ & $12.5 \mathrm{mg} / \mathrm{ml}$ & $6.25 \mathrm{mg} / \mathrm{ml}$ \\
\hline C. bacilli & $28 \pm 3 \mathrm{~mm}$ & $21 \pm 2 \mathrm{~mm}$ & $18 \pm 4 \mathrm{~mm}$ & $14 \pm 3 \mathrm{~mm}$ & $10 \pm 34 \mathrm{~mm}$ \\
S. typhi & $25 \pm 4 \mathrm{~mm}$ & $15 \pm 3 \mathrm{~mm}$ & $13 \pm 4 \mathrm{~mm}$ & - & - \\
S. aureus & $29 \pm 3 \mathrm{~mm}$ & $20 \pm 4 \mathrm{~mm}$ & $14 \pm 2 \mathrm{~mm}$ & $9 \pm 3 \mathrm{~mm}$ & - \\
\hline
\end{tabular}

\subsection{Phytochemical Analysis of the Crude and Various Metabolites}

Results of phytochemical analysis of various metabolites are presented in Table 6, from which it was observed that acidic metabolites contained amino acids, carboxylic acids, tannins, saponins, flavonoids and phenolic acids while the basic metabolites showed presence of alkaloids, amino acids, saponins and glycosides. The neutral metabolites contained amides, aldehydes, ketones, esters, steroids and terpenoids. 
Table 6. Phytochemical Screening of crude and various metabolites

\begin{tabular}{lcccc}
\hline Phytochemical & Crude extract. & Acidic metabolite & Basic metabolite & Neutral metabolite \\
\hline Alkaloids & + & - & ++ & - \\
Flavonoids & ++ & ++ & - & - \\
Cardioactive glycosides & ++ & + & ++ & - \\
Steroids \& triterpenes & ++ & - & - & ++ \\
Saponins & ++ & + & ++ & - \\
Tannins & +++ & + & ++ & - \\
Carboxylic acids & ++ & ++ & - & - \\
Esters & + & - & - & ++ \\
Aldehydes \& Ketones & + & - & - & + \\
Phenols & ++ & +++ & - & - \\
Amides & + & - & - & + \\
Amino acids & ++ & + & ++ & - \\
\hline
\end{tabular}

+++: Strongly Positive; ++: Positive; +: Weak; -: not detected.

\subsection{Chromatographic Purification of Acidic Metabolite}

The chromatographic purification of acidic metabolite gave five fractions numbered as AC1, AC2, AC3, AC4 and $\mathrm{AC} 5$, whose antimicrobial activities were evaluated against some human pathogenic microbes and compared to Amoxil; an orthodox antimicrobial drug (as positive control).

\subsection{Antimicrobial Screening of Various Fractions From Chromatographic Purification}

Antimicrobial results of various fractions obtained from the chromatographic purification of acidic metabolite were presented in Table 7. The effectiveness of these fractions and Control drug are represented by their inhibition zone diameters (IZD), measured in mm ( \pm std dev.) (Garred \& Graddy, 1983; Harbarth \& Samore, 2005; Wiley et al., 2008). The data showed that there was a direct proportionality between the drug or metabolite/fraction strength and the Inhibition Zone Diameter (IZD); that is; as the strength of the drug or metabolite/fraction increased against the microorganism the IZD also increased. Table 7 also showed that all the fractions (AC1, AC2, AC3, AC4 and AC5) exhibited inhibitory activities against Strep. spp. (gram positive bacteria responsible for several infectious diseases); $\mathrm{AC} 1$ was not effective against $S$. aureus and S. typhi, AC2 was ineffective against S. aureus while AC5 had no effect against C. albicans. AC3 and AC4 were effective against all the pathogens.

Table 7. Antimicrobial results of various fractions from chromatographic purification (Concentration $=30 \mathrm{mg} / \mathrm{ml}$; $\mathrm{IZD}=\mathrm{mm} \pm$ std dev.)

\begin{tabular}{lccccccc}
\hline Pathogen & AC1 & AC2 & AC3 & AC4 & AC5 & $\begin{array}{c}\text { Amoxil } \\
(30 \mathrm{mg} / \mathrm{ml})\end{array}$ & $\begin{array}{c}\text { Acidic } \\
\text { metabolite } \\
(25 \mathrm{mg} / \mathrm{ml})\end{array}$ \\
\hline Strep. spp & $15 \pm 3 \mathrm{~mm}$ & $20 \pm 3 \mathrm{~mm}$ & $20 \pm 4 \mathrm{~mm}$ & $15 \pm 4 \mathrm{~mm}$ & $12 \pm 3 \mathrm{~mm}$ & $20 \pm 4 \mathrm{~mm}$ & $15 \pm 4 \mathrm{~mm}$ \\
S. aureus & - & - & $20 \pm 5 \mathrm{~mm}$ & $15 \pm 3 \mathrm{~mm}$ & $10 \pm 6 \mathrm{~mm}$ & $10 \pm 5 \mathrm{~mm}$ & $20 \pm 5 \mathrm{~mm}$ \\
S. typhi & - & $10 \pm 6 \mathrm{~mm}$ & $15 \pm 3 \mathrm{~mm}$ & $10 \pm 5 \mathrm{~mm}$ & $10 \pm 4 \mathrm{~mm}$ & - & $10 \pm 5 \mathrm{~mm}$ \\
E. coli & $15 \pm 5 \mathrm{~mm}$ & $16 \pm 5 \mathrm{~mm}$ & $18 \pm 4 \mathrm{~mm}$ & $15 \pm 4 \mathrm{~mm}$ & $15 \pm 5 \mathrm{~mm}$ & $15 \pm 4 \mathrm{~mm}$ & $13 \pm 6 \mathrm{~mm}$ \\
C. bacilli & $16 \pm 3 \mathrm{~mm}$ & $15 \pm 4 \mathrm{~mm}$ & $20 \pm 4 \mathrm{~mm}$ & $15 \pm 2 \mathrm{~mm}$ & $10 \pm 5 \mathrm{~mm}$ & $20 \pm 4 \mathrm{~mm}$ & $20 \pm 5 \mathrm{~mm}$ \\
C. albicans & $17 \pm 4 \mathrm{~mm}$ & $15 \pm 5 \mathrm{~mm}$ & $18 \pm 5 \mathrm{~mm}$ & $15 \pm 4 \mathrm{~mm}$ & - & - & $\mathrm{ND}$ \\
\hline
\end{tabular}

Key: ND: not determined; -: abs. 
The control drug, Amoxil (at $30 \mathrm{mg} / \mathrm{ml}$ concentration) showed no activity against S. typhi and C. albicans. When compared with the control drug, it was observed that AC3 showed stronger antimicrobial potential against $S$. aureus but had the same activity against Strep. spp. and C. bacilli. Similarly, AC3 showed same effectiveness as the acidic metabolite against $S$. aureus and $C$. bacilli but was more active than the metabolite in its inhibition of Strep. spp.

Table 8. Chemical properties of fraction ac 3 (Based on laboratory observation)

\begin{tabular}{|c|c|c|}
\hline Chemical Tests & Observation & Inference \\
\hline Solubility in dilute acid & $\begin{array}{l}\text { The compound was insoluble in } \\
\text { dilute mineral acids }\end{array}$ & $\begin{array}{l}\text { Compound was not an amine; could be a } \\
\text { carboxylic acid, phenol or sulphonic acid. }\end{array}$ \\
\hline Solubility in dilute alkali & $\begin{array}{l}\text { Compound dissolved freely in } \\
\text { dilute alkali. }\end{array}$ & $\begin{array}{l}\text { Compound may be carboxylic acid, phenol } \\
\text { or sulphonic acid. }\end{array}$ \\
\hline Keto-enol tautomerism & $\begin{array}{l}\text { TLC showed compound existed } \\
\text { as two isomers, even after } \\
\text { chromatographic purification. }\end{array}$ & $\begin{array}{l}\text { This suggested the compound existed as } \\
\text { keto and enol forms. }\end{array}$ \\
\hline
\end{tabular}

\section{Discussion}

Interpretation of antimicrobial results presented in Table 1 could be made in terms of effectiveness of extract or metabolite; that is to say that the crude extract would be effective or bactericidal against $C$. bacilli $($ IZD $=27 \pm 3$ $\mathrm{mm}$ ), bacteriostatic or intermediate against $S$. typhi $(\mathrm{IZD}=21 \pm 3 \mathrm{~mm}$ ) and ineffective against $S$. aureus (IZD = $15 \pm 4 \mathrm{~mm}$ ). The acidic metabolite would be bactericidal against $C$. bacilli and $S$. aureus (IZD $=30 \pm 2 \mathrm{~mm}$ and $32 \pm 3 \mathrm{~mm}$ respectively) but bacteriostatic against $S$. typhi with IZD of $22 \pm 4 \mathrm{~mm}$ (Willey et al., 2008). The basic metabolite would be bacteriostatic against the microorganisms with IZD $=20 \pm 4,18 \pm 3$ and $15 \pm 5 \mathrm{~mm}$ respectively while the neutral metabolite would be bactericidal against all the microorganisms with IZD $=28 \pm 4$, $25 \pm 4$ and $29 \pm 3 \mathrm{~mm}$ respectively. According to Willey et al. (2008), S. aureus would be resistant against Penicillin G (positive control) when the IZD $\leq 20 \mathrm{~mm}$, bacteriostatic (or intermediate) when IZD $=21-28 \mathrm{~mm}$ and susceptible (or bactericidal) if IZD $\geq 29 \mathrm{~mm}$. However, for other pathogenic microorganisms, resistance to Penicillin G occurs if IZD $\leq 11 \mathrm{~mm}$, bacteriostatic if IZD = 12-14 $\mathrm{mm}$ and bactericidal when IZD $\geq 15 \mathrm{~mm}$. These differences in bioactivity arose probably from differences in phytochemical composition of the various metabolites (Ejele, 2010; Alinnor \& Ejele, 2009; Ejele \& Alinnor, 2010; Ejele \& Akujobi, 2011). Results of phytochemical analysis carried out on the various metabolites were presented in Table 6. The different constituents contained in various metabolites are substances that control cell growth and division, reduce inflammation, stimulate formation of blood cells and fight infections (Frazier \& Westhoff, 1995). Both acidic and neutral metabolites showed significant antibiotic activity against gram-positive S. aureus, the common flora of man and hospital environment. This is because this bacterium occurs in grape-like clusters on the skin and nose of healthy people and produces numerous toxins that cause toxic-shock syndrome and Staphylococcal scarlet fever (Ugbogu et al., 2010; Frazier \& Westhoff, 1995). It has been reported, all over the world, that $S$. aureus has developed resistance to most potent antibiotics which are used for treatment of diseases caused by this microorganisms and $95 \%$ of the strains were resistant to methicillin (Voravuthikunchai \& Kitpipit, 2005; Vindel et al., 2009). Therefore the need to obtain an effective drug against $S$. aureus cannot be overlooked. We cannot say (now) which of these phytochemical compounds was responsible for the observed antimicrobial properties of the acidic and/or neutral metabolite. However, it may be speculated that the carboxylic acids and/or polyphenols (flavonoids), amino acids and tannins which were dominant in the acidic metabolite or the steroids and terpenoids, which dominated in the neutral metabolite could be responsible for the observed effects because these had earlier been shown to possess bactericidal, fungicidal, virucidal and medicinal properties (Jussi-Pekka et al., 2000; Smith-Palmer et al., 2001; Kotzekidou et al., 2008; Evans, 2002; Cimanga et al., 2002; Bakkali et al., 2008). Thus the acidic metabolite, found in this study to inhibit activity of $S$. aureus with such wide inhibition zone diameter of $32 \pm 3 \mathrm{~mm}$, was further purified by column chromatography to isolate and characterize the active principle responsible for observed antimicrobial activity.

The chromatographic purification of acidic metabolite gave five fractions numbered as AC1, AC2, AC3, AC4 and $\mathrm{AC} 5$, whose antimicrobial potential were evaluated against some human pathogenic microbes and compared 
to Amoxil; an orthodox antimicrobial drug (as positive control). The effectiveness of these fractions and Control drug was represented by their inhibition zone diameter (IZD), measured in $\mathrm{mm}( \pm$ std dev.) (Garred \& Graddy, 1983; Harbarth \& Samore, 2005; Wiley et al., 2008). That is; as the strength of the drug or metabolite/fraction increased against the microorganism the IZD also increased. In view of the quantities and antimicrobial potential of different fractions obtained, AC3 was selected and analyzed by $\mathrm{IR},{ }^{1} \mathrm{H}-$ and ${ }^{13} \mathrm{C}-\mathrm{NMR}$ spectrometer and characterized.

Analysis of the IR spectrum revealed the broad peak at $3350 \mathrm{~cm}^{-1}$ probably due to hydrogen-bonded -OH group of alcohol or phenol; strong sharp peaks at $2927 \mathrm{~cm}^{-1}$ suggested the presence of aliphatic C-H groups, which was confirmed by peaks at 1452 and $1374 \mathrm{~cm}^{-1}$. The rather weak peaks around $1933 \mathrm{~cm}^{-1}$ suggested presence of aromatic ring. The strong sharp peak at $1713 \mathrm{~cm}^{-1}$ indicated the presence of carbonyl $(-\mathrm{C}=\mathrm{O})$ group of ketone or ester, while the peak at $1648 \mathrm{~cm}^{-1}$ suggested the presence of carbonyl $(-\mathrm{C}=\mathrm{O})$ group of amide or carboxylic acid or keto-enolic group of alpha hydroxyl ketone (Pavia et al., 1979). The strong sharp peak around 1270 and 1043 $\mathrm{cm}^{-1}$ suggested $-\mathrm{C}-\mathrm{O}$ stretching vibrations of ketone, alcohol, ester, ether or phenol while the peak at $973 \mathrm{~cm}^{-1}$ indicated the -C-H stretch of olefinic double bonds of alkenes.

Based on the IR spectrum, the Fluka library of Perkin Elmer (manufacturers of the equipment), suggested that AC3 could be one of the following compounds: Deoxycholic acid, (+)-Neomenthol, Chemodeoxycholic acid, Cyclopentadecanone, Naringin, Digitonin or Pentaacetic acid, methylthymol blue (sodium salt), streptomycin sulfate, or hydrocortisone acetate.

The ${ }^{1} \mathrm{H}-\mathrm{nmr}$ spectrum of $\mathrm{AC} 3$ showed an absorption peak at $\delta=7.2$ and 6.8 , probably indicated the presence of benzene ring, $\delta=5.2$, probably suggested presence of olefinic $-\mathrm{C}=\mathrm{CH}$ - bonds of unsaturated aliphatic compound; peak at $\delta=4.4$, probably showed presence of $-\mathrm{C}-\mathrm{H}$ group attached to carbon atom of an aromatic system $-\mathrm{C}_{6} \mathrm{H}_{4}-\mathrm{C}(\mathrm{R}) \mathrm{H}$, peak at $\delta=3.8$, may be due methoxyl group; the peak at $\delta=2.4$, may be due to presence of acetoxyl group $\mathrm{RCH}_{2} \mathrm{C}=\mathrm{O}$; strong proton absorption peaks around $\delta=1.0$, probably suggested the presence of methyl or methylene groups.

The ${ }^{13} \mathrm{C}-\mathrm{nmr}$ spectrum of AC3 showed a peak at $170 \mathrm{ppm}$ confirming presence of carbonyl group of ketone, aldehyde, amide, ester or carboxylic acid in the molecule while the peaks around 100-120 ppm confirmed presence of olefinic protons. The peaks around $130 \mathrm{ppm}$ confirmed presence of aromatic protons. The presence of aliphatic protons in the compound was confirmed by peaks in the region of 20-40 ppm (Finar, 1973; Pavia et al., 1979).

Hence, in view of the chemical properties of fraction AC3 observed in the laboratory (Table 8), it was concluded that the active principle in acidic metabolite of P. umbellatum (fraction AC3), could be a flavonoid, probably: Naringin (Figure 1).

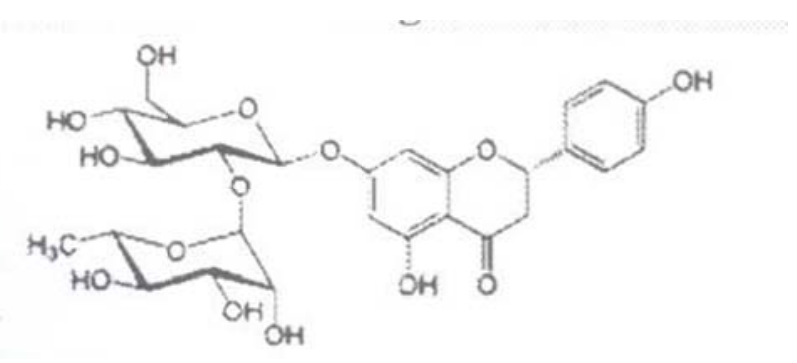

Figure 1. Naringin

Several authors have reported the isolation and characterization of useful compounds from P. umbellatum extract (Tabopda et al., 2008; Baldoqui et al., 2009). Tabopda et al. (2008) isolated four bioactive aristolactams from branches of $P$. umbellatum and showed they possessed $\alpha$-glucosidase inhibition, antioxidant and antifungal activities to various extents whereas Baldoqui et al. (2009) investigated the phytochemical composition of methanol extract of $P$. umbellatum leaves and isolated nine different compounds including one terpenoid glucoside, five flavones, two lignans and 4-nerolidylcathecol. The authors observed that except the 4-nerolidylcathecol, all the other compounds had not yet been isolated from the species (Baldoqui et al., 2009).

It has been documented since the middle ages that plant extracts and metabolites were used widely for bactericidal, fungicidal, virucidal, antiparasitic, insecticidal, medicinal and cosmetic purposes. Even now, they 
are often employed in sanitary, pharmaceutical, cosmetic, agricultural and food industries (Bakkali et al., 2008). These compounds possess preservative and antimicrobial effects when added to foods (Broughall \& Brown, 1984 ) and usually contained esters, terpenes, terpenoids, flavonoids and other phenol-derived aromatic and aliphatic compounds, most of which act as antioxidants (Jussi-Pekka et al., 2000; Smith-Palmer et al., 2001; Kotzekidou et al., 2008). Nevertheless, considering the fact that this study has suggested that Naringin could be the active principle in acidic metabolite of $P$. umbellatum, more work would be done to compare the antimicriobial activity of pure Naringin to $S$. aeureus with the results obtained in this study.

\section{Acknowledgements}

We wish to thank Emebiri Chika, Ezemenaka Michael and Ezebube Ngozi, for their contribution to this study.

\section{References}

Adesokan, A. A., Akanji, M. A., \& Yakubu, M. T. (2007). Antibacterial potentials of aqueous extract of Enantia chlorantha stem bark. African Journal of Biotechnology, 6(22), 2502-2505.

Ajayi, I. A., Ajibade, O., \& Oderinde, R. A. (2011). Preliminary phytochemical analysis of some plant seed. Research Journal of Chemical Sciences, 1(3), 58-62.

Alinnor, J. I., \& Ejele, A. E. (2009). Phytochemical Analysis and Antimicrobial Activity Screening of crude Extracts of leaves of Gongronema latifolium. Indian Journal of Botanical Research, 5, 161-168.

Anesini, E., \& Perez, C. (1993). Screening of plants used in Argentine folk medicine for antimicrobial activity. Journal of Ethnopharmacology, 39, 119-128. http://dx.doi.org/10.1016/0378-8741(93)90027-3

Bakkali, F., Averback, S., Averback, D., \& Idaomar, M. (2008). Biological effects of essential oils-A review. Food Chemistry and Toxicology, 46, 446-475. http://dx.doi.org/10.1016/j.fct.2007.09.106

Baldoqui, D. C., Bolzani, V. D. S, Furlan, M., Kato, M. J., \& Marques, M. O. M. (2009). Flavones, lignans and terpene from Piper umbellate (Piperaceae). Quimica Nova, 32(5), 1107-1109. http://dx.doi.org/10.1590/S0100-40422009000500005

Broughall, J. M., \& Brown, C. (1984). Hazard analysis applied to microbal growth in foods: development and application of three-dimensional models to predict microbial growth. Food Microbiology, 1, 13-22. http://dx.doi.org/10.1016/0740-0020(84)90005-4

Cimanga, K., Kambu, K., Tona, I., Apers, S., De Bruyne, T., Hermans, N., Totte, J., Pieters, L., \& Vlietinck, A. J. (2002). Correlation between the chemical composition and antibacterial activity of essential oils of some aromatic medicinal plants growing in the Democratic Republic of Congo. Journal of Ethnopharm, 79, 213-220. http://dx.doi.org/10.1016/S0378-8741(01)00384-1

Ejele, A. E. (2010). Effects of Secondary Metabolites of Cajanus cajan Extract on Sickling and Gelation of Human HbSS Erythrocytes. Nigerian Journal of Biochemistry and Molecular Biology, 25(2), 10-16.

Ejele, A. E., \& Akujobi, C.O. (2011). Effects of Secondary Metabolites of Garcinia kola on the Microbial Spoilage of Cajanus cajan Extract. International Journal of Tropical Agriculture and Food Systems, 5(1), 8-14.

Ejele, A. E., \& Alinnor, J. I. (2010). Anti-Sickling Potentials of Aloe vera Extract IV. Effects of Acidic, Basic and Neutral Metabolites on the Gelling and Sickling of human HbSS erythrocytes. International Journal of Natural and Applied Sciences, 6(2), 155-160.

Ejele, A. E., \& Ejele, N. U. (2012). Phytochemical Composition and Antimicrobial Potential of Piper Umbellatum Seed Extract and Its Acidic, Basic and Neutral Metabolites. Proceedings of the $35^{\text {th }}$ International Conference of the Chemical Society of Nigeria.

Ejele, A. E., Iwu, C. I., \& Ukiwe, L. N. (2012). Antimicrobial Potential of Neutral Metabolites of Piper umbellatum, Piper guineense, Ocimum gratissimum and Newbouldia laevis Extracts. International Journal of Natural and Applied Sciences, 8(1), 1-7.

Evans, W. C. (2002). Trease and Evans Pharmacognosy (pp. 221-225). W. B. Saunders Company Limited; Harcourt Publishers.

Finar, I. L. (1973). Organic Chemistry (Vol. 1, pp. 188-247; 363-372; 586-748). Fundamental Principles (6th Ed.). London: English Language Book Society \& Longman Group Limited.

Frazier, W. C., \& Westhoff, D. C. (1995). Food Microbiology (4th ed.). New Delhi: Tata McGraw-Hill Publisging Company Limited.

Garred, L. P., \& O-Graddy, F. (1983). Antibiotics and Chemotherapy (4th ed., p. 189). London: Churchill 
Livingstone Publishers.

Harbarth, S., \& Samore, M. H. (2005). Antimicrobial resistance determinants and future control. Emerging Infectious Diseases, 11, 794-801. http://dx.doi.org/10.3201/eid1106.050167

Juruya, E. Y., \& Lowry, F. D. (2006). Antimicrobial resistant bacteria in the Community setting. Nature Rev. Microbial, 4, 36-45. http://dx.doi.org/10.1038/nrmicro1325

Jussi-Pekka, R., Remes, S., Heinonen, M., Hopia, A., Kahkonen, M., Kujala, T., ... Vuorela, P. (2000). Antimicrobial effects of Finnish Plant extracts containing Flavonoids and other phenolic compounds. International Journal of Food Microbiology, 58, 3-12.

Kotzekidou, P., Giannakidis, P., \& Boulamatsis, A. (2008). Antimicrobial Activity of some plant extracts and essential oils against food borne pathogens in vitro and on the face of inoculated pathogens in chocolate. LWT-Food Science and Technology, 41, 119-127. http://dx.doi.org/10.1016/j.lwt.2007.01.016

Levy, S. (1998). The antibiotic paradox: How Miracle Drugs are destroying the Miracle (pp. 1-11). Plenum publishers.

Mahesh, B., \& Satish, S. (2008). Antimicrobial Activity of important medicinal plants against plant and human pathogen. World Journal of Agricultural Sciences, 4(5), 839-843.

Okwu, D. E. (2005). Phytochemicals, vitamins and mineral contents of two Nigerian medicinal plants. International Journal of Molecular Medicine and Advance Science, 1(4), 375-381.

Pavia, D. L., Lampman, G. A., \& Kriz, G. S. (1979). Introduction to Spectroscopy (pp. 15-73; 86-168). Philadelphia: Saunders College Publishing Company.

Pundir, R. K., \& Jain, P. (2010). Comparative studies on the antimicrobial activity of black pepper (Piper nigrum) and turmeric (Curcuma longa) extracts. International Journal of Applied Biology and Pharmaceutical Technology. 1(2), 492-500.

Smith-Palmer, A., Stewart, J., \& Fyfe, L. (2001). Potential application of plant essential oils as natural food preservatives in soft cheese. Food Microbiology, 18, 463-470. http://dx.doi.org/10.1006/fmic.2001.0415

Tabopda, T. K., Ngoupayo, J., Lui, J., Mitaine-Offer, A., Tanoli, S. A. K., Khan, S. N., ... Luu, B. (2008). Bioactive Aristolactams from Piper umbellate. Phytochemistry, 69(8), 1726-1731. http://dx.doi.org/10.1016/j.phytochem.2008.02.018

Ugbogu, O. C., Ahuama, O. C., Atusiuba, S., \& Okorie, J. E. (2010). Methicillin Resistant Staphylococcus aureus (MRSA) Amongst Students and Susceptibility of MRSA to Garcinia kola Extracts. Nigerian Journal of Microbiology, 24(1), 2043-2047.

Vindel, A., Cuevas, O., Cemado, E., Marcos, C., Bautista, V., Castellares, C., ... Bouza, E., \& the Spannish group for the study of Straphylococcus. (2009). Meticillin Resistant Straphylococcus aureus in Spain; Molecular epidemiology and utility of different typing methods. Journal of Clinical Microbiology, 47(16), 1620-1627. http://dx.doi.org/10.1128/JCM.01579-08

Voravuthikunchai, S. P., \& Kitpipit, L. (2005). Activity of Medicinal plant extracts against hospital isolates of methicillin resistant, Staphylococcus aureus. Clin. Microbiol. Infect., 11(6), $510-512$. http://dx.doi.org/10.1111/j.1469-0691.2005.01104.x

Wiley, J. M., Sherwood, L. M., \& Woolverton, C. J. (2008). In Preston, Harley and Klein's, Microbiology (7th ed., pp. 840-842). New York, USA: McGraw-Hill International edition.

World Health Organization. (1974). Toxicological evaluation of certain food additives with a review of general principles and specifications. WHO Technical Report Services, 539, Geneva.

\section{Copyrights}

Copyright for this article is retained by the author(s), with first publication rights granted to the journal.

This is an open-access article distributed under the terms and conditions of the Creative Commons Attribution license (http://creativecommons.org/licenses/by/3.0/). 